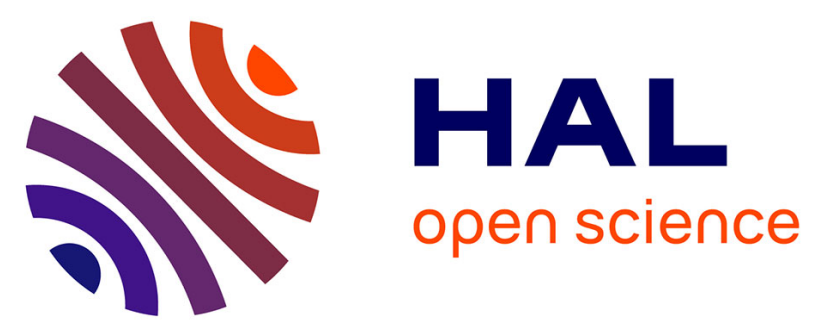

\title{
Mineralogy and pore water chemistry of a boiler ash from a MSW fluidized-bed incinerator
}

Françoise Bodénan, Dominique Guyonnet, Patrice Piantone, Philippe Blanc

\section{To cite this version:}

Françoise Bodénan, Dominique Guyonnet, Patrice Piantone, Philippe Blanc. Mineralogy and pore water chemistry of a boiler ash from a MSW fluidized-bed incinerator. Waste Management, 2010, 30 (7), p. 1280-1289. 10.1016/j.wasman.2010.01.020 . hal-00541518

\section{HAL Id: hal-00541518 https: / hal-brgm.archives-ouvertes.fr/hal-00541518}

Submitted on 30 Nov 2010

HAL is a multi-disciplinary open access archive for the deposit and dissemination of scientific research documents, whether they are published or not. The documents may come from teaching and research institutions in France or abroad, or from public or private research centers.
L'archive ouverte pluridisciplinaire HAL, est destinée au dépôt et à la diffusion de documents scientifiques de niveau recherche, publiés ou non, émanant des établissements d'enseignement et de recherche français ou étrangers, des laboratoires publics ou privés. 


\title{
MINERALOGY AND PORE WATER CHEMISTRY OF A BOILER ASH FROM A MSW FLUIDIZED-BED INCINERATOR
}

\author{
F. Bodénan*, D. Guyonnet, P. Piantone, P. Blanc \\ BRGM (French Geological Survey), Environment and Processes Division, BP 36009, 3 av. C. \\ Guillemin, 45060 Orléans Cedex \\ * corresponding author: Tel: (33) 238643441 - f.bodenan@brgm.fr
}

\begin{abstract}
:
This paper presents an investigation of the mineralogy and pore water chemistry of a boiler ash sampled from a municipal solid waste fluidized-bed incinerator, subject to 18 months of dynamic leaching in a large percolation column experiment. A particular focus is on the redox behaviour of $\mathrm{Cr}(\mathrm{VI})$ in relation to metal aluminium $\mathrm{Al}^{0}$, as chromium may represent an environmental or health hazard. The leaching behaviour and interaction between $\mathrm{Cr}(\mathrm{VI})$ and $\mathrm{Al}^{0}$ are interpreted on the basis of mineralogical evolutions observed over the 18-month period and of saturation indices calculated with the geochemical code PhreeqC and reviewed thermodynamic data. Results of mineralogical analyses show in particular the alteration of mineral phases during leaching (e.g. quartz and metal aluminium grains), while geochemical calculations suggest equilibria of percolating fluids with respect to specific mineral phases (e.g. monohydrocalcite and aluminium hydroxide). The combination of leaching data on a large scale and mineralogical analyses document the coupled leaching behaviour of aluminium and chromium, with chromium appearing in the pore fluids in its hexavalent and mobile state once metal aluminium is no longer available for chromium reduction.
\end{abstract}

Key words: MSW ash, fluidized-bed, leaching, Al metal, Cr(VI), PhreeqC.

\section{Introduction}

Fluidized-bed combustion (FBC) is a well established technology for burning coal (Valk, 1994), sometimes in combination with biomass (Gogebakan and Selçuk, 2009) or for burning relatively homogeneous wastes such as sewage sludge (Van de Velden et al., 2008, Toledo et al., 2005). In recent years, the technology has sometimes been applied to the thermal 


\section{To be published in Waste Management (2010) - Bodénan et al.}

treatment of municipal solid waste (MSW; Rhyner et al., 1995), but such an application remains an exception. In France for example, out of the $128 \mathrm{MSW}$ thermal treatment units in operation since 2005 , only 4 were based on the FBC technology, while the remaining units relied on the grate kiln (stationary or moving grate) technology.

The basic principle of FBC is the injection of air at the base of the combustion chamber through a layer of inert material (typically sand) which generates a suspended mass of waste and sand particles. This improves waste particle combustion due to the greater contact surface between the waste and the sand, with the drawback however that the waste must be shredded to a particle size of around 100 to $300 \mathrm{~mm}$, following the type of technology used. This type of thermal treatment generates four solid residues: on the one hand air pollution control (APC) residues and bottom ash, typical of grate kiln incinerators, and on the other hand hopper ash and cyclone ash. Note that the ash studied in this paper and referred to as "boiler ash", is analogous to what Abbas et al. (2003) refer to as "hopper ash" (see Fig. 1 of Abbas et al., 2003). According to Abbas et al. (2003), among the advantages of the FBC technology are the low NOx and SOx emissions, the efficiency of heat transfer from the sand bed to the heat exchanger walls and the low amount of unburned matter in the ash residues.

As a result of the limited extent of FBC technology compared to grate kiln incinerators in the thermal treatment of MSW, relatively few studies have addressed the chemical composition and mineralogy of the residues. Abbas et al. (2003) examined the extraction, using batch leaching tests, of salts from filter ash, cyclone ash, hopper ash and bottom ash sampled from two FBC boilers in Sweden. Abbas et al. (2001) focused in particular on the leaching behaviour of chromium in different types of FBC ash (bottom, hopper, cyclone and filter ashes). These authors underline the influence of $\mathrm{Al}^{0}$ on chromium speciation and hence mobility.

The leaching behaviour of chromium in ash from waste thermal treatment plants has also been studied by Astrup et al. (2005; 2006). Astrup et al. (2005) provide a conceptual model for the interaction between $\mathrm{Cr}, \mathrm{Al}$ and oxygen that was applied by Guyonnet et al. (2008) to reproduce the leaching behaviour observed during leaching experiments performed at several scales on a boiler ash from a FBC plant in France. This paper provides additional data for this same boiler ash with a special focus on the ash mineralogy and geochemical equilibria in pore waters collected during the leaching experiment performed in a large column. The new data provide additional insight into the composition and leaching behaviour of such residues.

\section{Materials and Methods}




\subsection{Material preparation}

The thermal process residue studied herein is a boiler ash from a French rotary fluidized-bed MSW incineration plant, which burns around 54,000 tons of waste annually. Eighteen tons of boiler ash were recovered in big bags and dried in a depot from an initial water content of around 10 weight percent to approximately $0.5 \%$. Because preliminary studies of the ash's reactivity indicated a risk of setting during percolation experiments, it was mixed in equal weight proportions with washed Loire sand $(0.1-1 \mathrm{~mm})$. A horizontal continuous feed pugmill fed by two circuits; one for sand and one for ash, was used to guarantee homogeneous mixing between the two materials. The flowrates of the two circuits were checked approximately every 15 minutes. A flowsheet of the preparation of the ash-sand mixture can be found in Guyonnet et al (2005).

Following mixing, twenty measurements of the ash-sand dry density yielded an average value of $1.32 \mathrm{~g} / \mathrm{cm}^{3}$ with a standard deviation of $0.035 \mathrm{~g} / \mathrm{cm}^{3}$. However, during the filling up of the column experiment described below, some consolidation occurred and overall dry density increased slightly to $1.39 \mathrm{~g} / \mathrm{cm}^{3}$. The grain size of the ash-sand mixture was below 2 $\mathrm{mm}$, with a $10 \%$ fraction between 10 and $100 \mu \mathrm{m}$._Chemical and mineralogical analyses were performed on the raw ash and on the ash-sand mixture before and after 18 months of dynamic leaching.

\subsection{Global chemical analyses of the solids}

Chemical analyses were performed by ICP-AES after alkaline fusion using $\mathrm{Na}_{2} \mathrm{O}_{2}$ at $450^{\circ} \mathrm{C}$ and then digestion by $\mathrm{HCl}$ (method adapted from NF ISO 14869-2, 2002). Major elements (Ca, Si, Al, Fe, K, Mg, Mn, Na, P, Si, Ti) in the fresh ash were also determined by X-ray fluorescence (Philips PW2400, sequential) following sample preparation using the bead technique (addition of a fluxing agent; lithium tetraborate). Chloride was determined by potentiometric analysis. Total sulphur, total carbon and inorganic carbon were determined by non-dispersive infrared analysis of the gases $\mathrm{CO}_{2}$ and $\mathrm{SO}_{2}$ released following specific treatments: digestion by a $25 \%$ phosphoric acid solid for inorganic carbon, and oxidation under $\mathrm{O}_{2}$ at $900^{\circ} \mathrm{C}$ for total carbon and total sulphur. The amount of organic carbon was derived by subtracting inorganic carbon from total carbon $\left(\mathrm{C}_{\mathrm{org}}=\mathrm{C}_{\mathrm{tot}}-\mathrm{C}_{\mathrm{inorg}}\right)$. 


\section{To be published in Waste Management (2010) - Bodénan et al.}

Contents of $\mathrm{Al}^{0}$ and $\mathrm{Cr}(\mathrm{VI})$ in the solid were analyzed before and after leaching in the large column. Hexavalent chromium in the solid was analyzed colorimetrically following a reaction between $\mathrm{Cr}(\mathrm{VI})$ and 1,5-diphenylcarbohydrazide, under alkaline and warm conditions (EPA $3060 \mathrm{~A}$ and 7196). Independent checks were performed by adding known amounts of $\mathrm{K}_{2} \mathrm{CrO}_{4}$ and $\mathrm{Cr}$ (III). Metal aluminium was measured by atomic adsorption spectroscopy following a controlled attack in a methanol-brome medium (Young, 1974). Crystallisation water was measured using the Penfield tube method (Sandell, 1951). Uncombined lime was determined by the classical ethylene glycol method (MacPherson and Forbrich, 1937).

\subsection{Mineralogical characterisation of the fresh and leached ash}

Crushed powders washed sand and five boiler ash grain-size fractions $(500 \mu \mathrm{m}-2 \mathrm{~mm} ; 250$ $500 \mu \mathrm{m} ; 125-250 \mu \mathrm{m} ; 63-125 \mu \mathrm{m} ;<63 \mu \mathrm{m}$ ) were analysed by X-Ray Diffraction before leaching to identify major phases. The diffractometer with a Bragg Brentano geometry (Siemens D5000) is equipped with a monochromator and with a cobalt $\mathrm{K}_{\alpha 1}$ radiation $(\lambda=$ $1.78897 \AA$ ). Acquisition time for the XRD patterns in the $4-84^{\circ} 2 \theta$ interval was set at one second per $0.02^{\circ} 2 \theta$ step ( $=1$ hour) for rotating samples. The phyllitic fraction of the sand (clays) was determined according to standard methodology on oriented samples with and without glycol during $12 \mathrm{~h}$ and then heated at $490^{\circ} \mathrm{C}(4 \mathrm{~h})$. The crystalline phases were identified using Diffrac-AT software, in conjunction with the JCPDS (Joint Committee on Powder Diffraction Standards) database.

Micro-characterisation of the samples was performed in order to confirm XRD results with respect to major crystalline phases, to identify minor and amorphous phases and to detect trace elements in the phases by element mapping and quantitative analyses. Polished thin sections of fresh ash and leached ash-sand, were examined under a scanning electron microscope (SEM) with qualitative energy dispersive spectroscopy (EDS), and a Cameca SX 50 electronic microprobe (EMP) with quantitative wavelength dispersive spectroscopy (EWS). Additional raw samples of fresh ash were observed by SEM-EDS. EMP conditions for element mapping were an acceleration voltage of $15 \mathrm{kV}$ and a reference current of $14 \mathrm{nA}$. EMP spot analyses were performed with an acceleration voltage of $15 \mathrm{kV}$ and a reference current of $14 \mathrm{nA}$. Counting time was 6 seconds for the major elements and 20 seconds for the trace elements. The used standards were: albite for $\mathrm{NaK} \alpha$ and $\mathrm{SiK} \alpha$, orthose for $\mathrm{KK} \alpha, \mathrm{Al} 2 \mathrm{O} 3$ for $\mathrm{AlK} \alpha, \mathrm{MnTiO} 3$ for $\mathrm{TiK} \alpha$ and $\mathrm{MnK} \alpha$, andradite for $\mathrm{CaK} \alpha, \mathrm{Fe} 2 \mathrm{O} 3$ for FeK $\alpha$, forsterite for 
$\mathrm{MgK} \alpha$, vanadinite for $\mathrm{ClK} \alpha$, barytine for $\mathrm{SL} \alpha$, fluorapatite for $\mathrm{PK} \alpha, \mathrm{Cr} 2 \mathrm{O} 3$ for $\mathrm{CrK} \alpha, \mathrm{Cu}$ metal for $\mathrm{CuK} \alpha, \mathrm{PbS}$ for $\mathrm{PbM} \alpha, \mathrm{ZnO}$ for $\mathrm{ZnK} \alpha$. Matrix effect corrections were performed with the "PAP" model (Pouchou and Pichoir, 1991).

\subsection{Dynamic and static leaching tests -Water analyses}

A downward-flow percolation experiment was performed in a large column described in Guyonnet et al. (2008). In summary the column is 5 metres high, 1 metre in diameter and equipped with an outlet at the bottom and 5 porous cups, noted PC1 through PC5, installed at $0.8,1.82,2.54,3.55$, and $4.36 \mathrm{~m}$ from the waste surface respectively. Data collected at different depths within the column provide an opportunity to investigate scale effects for a given infiltration rate. Infiltration of demineralised water was controlled automatically by sprinklers at the top of the column which sprayed 10 litres every 8 hours (30 litres/day) resulting, taking into account the column areas (one meter diameter), in an infiltration of approximately $3.8 \mathrm{~cm} /$ day. Porewater and effluent concentrations were monitored during 18 months, providing samples at final liquid/solid (L/S) values ranging from $3 \mathrm{~L} / \mathrm{kg}$ at the outlet to $20 \mathrm{~L} / \mathrm{kg}$ for the uppermost porous cup (PC1).

Prior to chemical analyses, all water samples were filtered at $0.45 \mu \mathrm{m}$ and sub-samples were acidified at $\mathrm{pH} 2$ for cation analyses. Dissolved concentrations including total $\mathrm{Cr}$ were determined using standard methods by ICP-AES with a sequential Jobin Yvon JY 38 device (NF EN ISO 11885) and ionic chromatography (NF EN ISO 10304). Total inorganic carbon was analysed by infra-red spectroscopy on samples placed on a sealed tube with a septum in order to avoid carbonation. Cr(VI) was analysed by molecular absorption spectroscopy (NF T 90-043). Results showed that dissolved Cr was only present as Cr(VI) and therefore ICP-AES results on $\mathrm{Cr}_{\text {total }}$ were taken as $\mathrm{Cr}(\mathrm{VI})$ concentrations because of the lower quantification limit ( $5 \mu \mathrm{g} / 1$ for the ICP-AES as compared to $10 \mu \mathrm{g} / 1$ for the colorimetric method). Due to the relative abundance of aluminium, which may form colloids in waters at neutral values of $\mathrm{pH}$, ultrafiltration at 4000 daltons was performed on several samples and analysed for $\mathrm{Al}, \mathrm{Ca}$, $\mathrm{SiO}_{2}$ and $\mathrm{SO}_{4}$. Results showed no significant differences with data measured in water samples filtered at 0.45 or $0.1 \mu \mathrm{m}$.

At the end of the 18-month leaching period, the large column was carefully dismantled and samples were collected at different depths, along the central axis of the column, for analysis. Samples were collected and homogenised from each 1-metre section and analysed; a composite sample of the entire column was also created by quartering of these sub-samples. 


\section{To be published in Waste Management (2010) - Bodénan et al.}

The batch leaching test for granular waste at a liquid/solid $(\mathrm{L} / \mathrm{S})$ ratio of $10 \mathrm{~L} / \mathrm{kg}$ was performed (CEN, 2002). During the dismantling procedure, it was observed that the material was loose and didn't show evidence of localized consolidation, concretions, colouring, etc., such as could be observed for example in bottom ash leaching experiments (Piantone et al., 2004). It is therefore hypothesized that, due to the material's homogeneity and grainsize, and to even distribution of flow at the column head, preferential flow was probably not significant.

\section{Results and discussion}

\subsection{Global chemical composition before and after leaching}

Table 1 completes data presented in Guyonnet et al. (2008) and provides a comparison with data from Abbas et al. (2001). Major elements in the ash sand mixture are related to the presence of Si-rich oxidized phases and to a lesser extent to the presence of $\mathrm{Al}, \mathrm{Ca}, \mathrm{Fe}$ and $\mathrm{K}$. Trace elements in the ash-sand mixture are, by order of decreasing importance, $\mathrm{Zn}, \mathrm{Cu}, \mathrm{Ba}$, $\mathrm{Pb}, \mathrm{Sn}$, Sr. Uncombined lime content (free and hydrated lime, respectively $\mathrm{CaO}$ and $\mathrm{Ca}(\mathrm{OH})_{2}$ ) is low $(<0.5 \mathrm{mg} / \mathrm{Kg})$. The proportion of zero-valent (metal) aluminium is $1.4-1.45 \mathrm{wt} \%$ (2 analyses), i.e., $23 \mathrm{wt} \%$ of the total aluminium. A similar characterisation of the waste after 18 months of leaching in the large column shows a decrease in the proportion of metal aluminium to $0.54 \mathrm{wt} \%$ suggesting that on average, $60 \%$ of metal aluminium has been altered. The significant increase of crystallisation water $(0.7$ to $1.7 \%$ after 18 months of leaching) suggests the formation of hydrated minerals, probably of the ettringite type $\mathrm{Ca}_{6} \mathrm{Al}_{2}\left(\mathrm{SO}_{4}\right)_{3} \cdot 26 \mathrm{H}_{2} \mathrm{O}$ as identified by SEM-EDS (Fig. 2b). As seen in Table 1, data from Abbas et al. (2001) measured on a FBC hopper ash, show values very similar to those measured in this study.

Analyses of $\mathrm{Cr}(\mathrm{VI})$ in the fresh ash (not included in Table 1) yielded values between 1.3 and $1.6 \mathrm{mg} / \mathrm{Kg}$. But these values are most certainly underestimated since control tests with $\mathrm{K}_{2} \mathrm{CrO}_{4}$ and $\mathrm{PbCrO}_{4}$ spikes showed that only $25 \%$ of the added $\mathrm{Cr}(\mathrm{VI})$ was recovered. Such analytical difficulties are also reported by Abbas et al. (2001) and are related to an analytical bias: the selective attack of the ash under alkaline and warm conditions, in presence of metal aluminium which is oxidized, promotes the reduction of $\mathrm{Cr}(\mathrm{VI})$ to $\mathrm{Cr}$ (III). Similar analyses on the ash-sand following 18 months of leaching yielded $3.5 \mathrm{mg} / \mathrm{Kg} \mathrm{Cr}(\mathrm{VI})$. This result is believed to be reliable because independent checks with spikes of $\mathrm{K}_{2} \mathrm{CrO}_{4}$ and $\mathrm{PbCrO}_{4}$ 
indicated total recovery of added Cr. This is explained by a "passivation" of metal aluminium $\mathrm{Al}^{0}$ following the 18 months of dynamic leaching, which no longer promotes a reduction of $\mathrm{Cr}(\mathrm{VI})$ to $\mathrm{Cr}(\mathrm{III})$. This is confirmed by mineralogical analysis (next section) which shows a clear alteration of $\mathrm{Al}^{0}$ grains and neoformation of $\mathrm{Al} / \mathrm{O}$ precipitates following leaching, most probably $\mathrm{Al}(\mathrm{OH})_{3}$ considering the alkaline $\mathrm{pH}$. The clear redox relationship between aluminium and chromium is also clear from the porewater chemistry shown below.

\subsection{Mineralogical phases}

From XRD analyses of five grain-size fractions, the fresh ash contains primarily quartz, silicates (microcline, plagioclase, diopside, gehlenite), carbonates such as calcite, some sulphates (anhydrite), iron oxides (hematite) and halite. The background noise of the fresh ash diffractograms (Fig. 3), i.e., truly amorphous phases and crystalline phases present in proportions too small to be detected, is quite significant. Furthermore a diffuse bump centred around $34^{\circ} 2 \theta$ is clearly noticed for the limiting grain-size grain fractions $(>500 \mu \mathrm{m}$ and $<63$ $\mu \mathrm{m})$ indicating the presence of poorly organized crystalline structures. This is confirmed by optical microscopy on the $<63 \mu \mathrm{m}$ fraction which showed numerous vitreous microspheres. From XRD analysis, the sand contains quartz (around 45\%), microcline, plagioclase, augite and a small portion of clay of illite/mica type. The predominance of the phases was confirmed by SEM (Fig. 1), qualitative EDS analyses and quantitative EMP analyses.

Calcium phosphates were also identified by microscopic analyses (SEM-EDS and EMP). Note that XRD, which is typically used to detect crystalline phases above $1-5 \%$, was not applied to samples collected after leaching in the large column because i) of the mixing with sand (50/50) and ii) the probably poorly crystalline state of neoformed minerals. Therefore direct microscopic analyses were preferred. The composition of calcium phosphates shows an increase of calcium content with leaching. While $\mathrm{Ca} / \mathrm{P}$ ratios were initially close to $0.9-1.2$, they increased to 1.4-1.6 at the end of the leaching experiment, confirming the greater stability of the resulting phosphates which probably evolved from monetite $(\mathrm{Ca} / \mathrm{P}=1)$ to the more stable whitlockite $(\mathrm{Ca} / \mathrm{P}=1.5)$ and finally apatite type $(\mathrm{Ca} / \mathrm{P}=1.87)$.

Micro-mappings of a large selection of elements present in the ash reveal that $\mathrm{Al}$ is mainly present as $\mathrm{Al}^{0}$ and $\mathrm{Al}$ hydroxyde, $\mathrm{Ba}$ as sulphate, $\mathrm{Cu}$ as $\mathrm{Cu}^{0}, \mathrm{CuO}$ or $(\mathrm{Cu}, \mathrm{Mn}) \mathrm{O}, \mathrm{Mn}$ as $(\mathrm{Mn}, \mathrm{Zn}) \mathrm{O}$, Ti as $\mathrm{TiO}_{2}$ and $\mathrm{Zn}$ as $(\mathrm{Zn}, \mathrm{Mn}) \mathrm{O}$. SEM images in Fig. 1 show that the quartz grains are coated with a Ca-bearing phase which may constitute the reactive part of the ash and is probably analogous to a cement-type phase. Microscopic analyses (SEM-EDS and EMP) of the waste after 18 months of leaching in the large column show the alteration of quartz and 


\section{To be published in Waste Management (2010) - Bodénan et al.}

feldspar grains (development of micro-fissures) as well as the precipitation of aluminium hydroxides and most probably of hydrated phases such as ettringite $\left(\mathrm{Ca}_{6} \mathrm{Al}_{2}\left(\mathrm{SO}_{4}\right)_{3} \cdot 26 \mathrm{H}_{2} \mathrm{O}\right)$ (Fig. 2). The latter phase was largely suspected from SEM-EDS qualitative analyses (from Al, $\mathrm{Ca}$ and $\mathrm{S}$ contents) and from quantitative microprobe analysis performed on small grains which revealed a non-stoechiometric phase consistent with a mixture of phases such as $\mathrm{Al}(\mathrm{OH})_{3}$, ettringite and calcium sulphates. Both ettringite and $\mathrm{Al}(\mathrm{OH})_{3}$ are known to generate swelling in materials or roads during exothermic reactions. Although no significant swelling related to such phases was detected in the large column, swelling may have occurred as suggested by temperature variations measured in the large column during the first twenty days of leaching. Significant swelling was observed in lysimeter cells described in Guyonnet et al. (2008). Other cement-type phases, referred to below in the geochemical calculations, were not clearly identified.

\subsection{Results of leaching tests}

While data from the outlet of the large column were shown in Guyonnet et al. (2008), Fig. 3 shows the evolution over time of $\mathrm{pH}, \mathrm{Eh}, \mathrm{Al}$ and $\mathrm{Cr}(\mathrm{VI})$ measured in all the porous cups (PC) of the column, as well as at the outlet. The $\mathrm{pH}(11.5-12)$ is typical of alkaline incineration residues, while the redox potential (Eh) increased gradually from slightly reducing conditions (approximately -100 to $0 \mathrm{mV}$ from the outlet to the uppermost porous cup) to more oxidising conditions at the end of the experiment ( 0 to $300 \mathrm{mV}$ from the base to the top).

Figure 3 shows a remarkable inverse correlation between measured aluminium and chromium concentrations: $\mathrm{Cr}(\mathrm{VI})$ starts to appear when $\mathrm{Al}$ decreases. This was interpreted by Guyonnet et al. (2008), in agreement with Astrup et al. (2005), as a coupled effect between the oxidation of $\mathrm{Al}^{0}$ on the one hand and the reduction of $\mathrm{Cr}(\mathrm{VI})$ to $\mathrm{Cr}$ (III) on the other hand. It is only after approximately 130 days that $\mathrm{Cr}(\mathrm{VI})$ starts to appear in the uppermost porous cup (PC1). Before that time, chromium is in its reduced and less mobile state $\mathrm{Cr}(\mathrm{III})$. Once the metal aluminium has been "passivated" (Figs. 2c and 2d), aluminium concentrations decrease and chromium is mobilized as $\mathrm{Cr}(\mathrm{VI})$.

The porewater data collected from the large column is plotted in Fig. 4 as a function of depth at specific times. As seen in Fig. 4a, $\mathrm{pH}$ values remain high $(>11)$ throughout the column, but there appears to be a pH gradient with a slightly upward trend as depth increases. The redox potential measurements (Fig. 4b) suggests slightly more oxidizing conditions in the upper portion of the column (with an outlier at PC5; $4.36 \mathrm{~m}$ ), as a result of the inflow of 
oxygen-rich demineralised water fed at the top of the column. In Guyonnet et al. (2008) it was shown that it was necessary to account for the transport of dissolved oxygen (see Astrup et al., 2005) in order to reproduce the observed $\mathrm{Al}$ and $\mathrm{Cr}$ concentrations. The remarkable inverse correlation between $\mathrm{Al}$ and $\mathrm{Cr}(\mathrm{VI})$ is again illustrated by Figs. 4c and $4 \mathrm{~d}$.

Batch leaching tests performed at $\mathrm{L} / \mathrm{S}=10(\mathrm{CEN}, 2002)$ on samples collected at different depths within the large column after 18 months leaching are shown in Table 2. The L/S values shown are the average values reached by the sampled sections over the 18-month period. Results obtained on the fresh ash-sand mixture are shown for comparison. Due to the liquidsolid ratios achieved in the column at the end of testing (more than $20 \mathrm{~L} / \mathrm{Kg}$ at the top; $3 \mathrm{~L} / \mathrm{Kg}$ at the bottom), the quantities leached from the fresh ash-sand mixture are generally much higher than from the samples collected from the large column. This does not appear to be the case however for $\mathrm{Cr}(\mathrm{VI})$, due on the one hand to the oxidation of $\mathrm{Cr}(\mathrm{III})$ to $\mathrm{Cr}(\mathrm{VI})$ during the percolation experiment, in accordance with the observed trend towards more oxidizing conditions (Fig. 3b), and on the other hand to an underestimation of the $\mathrm{Cr}(\mathrm{VI})$ concentration in the fresh ash-sand due to the presence of $\mathrm{Al}^{0}$.

In Table 2, the $\mathrm{pH}$ value of 10.3 measured during batch leaching of the fresh ash-sand mixture may seem low compared to the $\mathrm{pH}$, around $\mathrm{pH} 11$, measured after leaching in the large column. However, this is consistent with the trend observed at the beginning of leaching in the large column (see Fig. 3a), where pH started quite low (around 8.7) and then increased with time and $\mathrm{L} / \mathrm{S}$ ratio. It is known that the release of sodium and potassium, present in other minerals than salts, can occur with a delay in clinker/cement type materials (and depends largely on grain size). For example Taylor (1990) shows that, in the case of fresh cement pastes, this phenomenon gives higher $\mathrm{pH}$ values than in the case of equilibrium with portlandite $\mathrm{Ca}(\mathrm{OH})_{2}$. Such a mechanism seems plausible for the high-temperature glass matrix of the ash and can help explain higher $\mathrm{pH}$ values at the end of leaching than in the fresh ash-sand mixture.

\subsection{Geochemical equilibria}

Thermodynamic calculations were performed in order to estimate saturation indices (SI) of the waters with respect to selected minerals, using version 2.12 of the PHREEQC geochemical code (Parkhurst and Appelo, 1999). Thermodynamic data are from the associated database Llnl.dat, with additional references for cement-type phases (Table 3) obtained from a review of thermodynamic data at different temperatures (Blanc et al., 2008). 
Speciation calculations were performed on solutions with a charge balance error lower than $5 \%$. Ionic strengths of waters were calculated. Considering the $0.5 \mathrm{eq} / \mathrm{L}$ limit given by Appelo et Postma (1999) for the Davies model activity used in PHREEQC outlet waters are to be considered only above L/S 0.3 . All porous cup waters were validated $(<0.5 \mathrm{eq} / \mathrm{L})$.

Results in Fig. 5, plotted versus liquid-to-solid ratio (L/S), suggest that water samples collected at the outlet of the large column are in equilibrium with respect to monohydrocalcite, barite, wollastonite and aluminium hydroxide; $\mathrm{Al}(\mathrm{OH})_{3}$ (Fig. 5a). Outlet waters are under-saturated with respect to gypsum and, as expected at a $\mathrm{pH}$ around 11.5, to portlandite. Saturation indices are also shown for some cement-type phases in Fig. 5b: values show important fluctuations for monocarbo-aluminate, calcium-aluminates (straëtlingite, hydrogarnet, $\mathrm{C}_{4} \mathrm{AH}_{13}, \mathrm{Ca}_{2} \mathrm{Al}_{2} \mathrm{O}_{5}: 8 \mathrm{H}_{2} \mathrm{O}$ ) and ettringite, suggesting that these phases do not reach equilibrium within the bulk of the column during the experiment. However, precipitation of these phases could occur locally, considering heterogeneity in the large column, as indicated by Fig. $2 \mathrm{~b}$ where ettringite was identified by microscopy.

Calculations performed with the chemistries measured in the samples collected from the porous cups (Fig. 6) suggest a trend towards equilibrium with respect to straëtlingite at high values of $\mathrm{L} / \mathrm{S}$ value $(>15)$, while waters become undersaturated with respect to Microcrystalline Gibbsite, $\mathrm{Al}(\mathrm{OH})_{3} \mu \mathrm{C}$. In all cases, the samples appear to be in equilibrium with respect to monohydrocalcite. Hyks et al. (2009a and 2009b) also observed a trend towards equilibrium with respect to straëtlingite, in porewaters collected during column experiments with MSWI bottom ash and MSWI fly ash/APC residues.

The data presented herein confirm the conceptual model proposed by Astrup et al. (2005). Chromium appears at the outlet of the column once aluminium decreases in all the porous cups of the large column, suggesting the simultaneous oxidation of metal aluminium $\left(\mathrm{Al}^{0}\right)$ to $\mathrm{Al}(\mathrm{III})$ with a reduction of $\mathrm{Cr}(\mathrm{VI})$ to $\mathrm{Cr}(\mathrm{III})$ :

$$
\mathrm{Al}^{0}+\mathrm{CrO}_{4}{ }^{2-}+4 \mathrm{H}_{2} \mathrm{O} \rightarrow \mathrm{Al}(\mathrm{OH})_{4}^{-}+\mathrm{Cr}(\mathrm{OH})_{3}(\mathrm{~s})+\mathrm{OH}^{-}
$$

So long as there is $\mathrm{Al}^{0}$ to oxidize, chromium is in its non mobile trivalent form. However, as shown also by Astrup et al. (2005), two competitive reactions are also involved:

$$
\begin{aligned}
& \mathrm{Al}^{0}+0.75 \mathrm{O}_{2}+1.5 \mathrm{H}_{2} \mathrm{O}+\mathrm{OH}^{-} \rightarrow \mathrm{Al}(\mathrm{OH})_{4}^{-} \\
& \mathrm{Al}^{0}+\mathrm{OH}^{-}+3 \mathrm{H}_{2} \mathrm{O} \rightarrow \mathrm{Al}(\mathrm{OH})_{4}^{-}+1.5 \mathrm{H}_{2}
\end{aligned}
$$


Note that Eq. (3) involves the production of hydrogen. Hydrogen gas production was observed during batch ageing tests performed with the ash-sand mixture. Measured molar $\mathrm{H}_{2}$ gas fractions were around $10 \%$ on average. Equations (2) and (3) tend to deplete the reducing capacity of $\mathrm{Al}^{0}$, leading to $\mathrm{Cr}$ mobility as $\mathrm{Cr}(\mathrm{VI})$. These mechanisms are consistent with observations in the large column where redox conditions evolved gradually towards more oxidizing conditions (Fig. 3b). As shown in Guyonnet et al. (2008), observed breakthroughs of chromium and aluminium in the column can be reproduced with a coupled chemistrytransport model (PHREEQC; Parkhurst and Appelo, 1999), taking into account Eqns. (1) through (3) and reaction kinetics.

\section{Conclusions}

The data presented herein illustrate the importance of mineralogical characterisation for a better understanding of the leaching behaviour of waste materials. Mineralogical and pore fluid equilibria calculations provide information regarding mineral phases controlling the solubilities of key elements such as $\mathrm{Al}$ and $\mathrm{Cr}$, which can then be used for the quantitative interpretation of observed leaching behaviours, with the help of coupled chemistry-transport models (see Guyonnet et al., 2008). The mineralogical observations presented herein document the ageing process undergone by the ash during the leaching experiment, with an alteration of mineral phases such as metal aluminium or quartz and silicates. SEM images document the precipitation of hydrated neo-formed mineral phases such as ettringite or aluminium hydroxides, which can have negative implications for the reuse of the material (e.g. in roadworks), due to swelling.

The detailed pore water chemistry monitored during 18 months of leaching clearly illustrates the coupled behaviour of aluminium and chromium, with chromium appearing in percolating fluids in its mobile (hexavalent) form, when metal aluminium is no longer available for chromium reduction. Such breakthrough of chromium is an environmental and health concern and a potential reason why this boiler ash might not be accepted by environmental regulators as a candidate for utilisation (e.g. in roadworks). If it were not for this element, this ash could comply with the inert waste acceptance criteria (OJC, 2003), provided a "factor 3" is used for sulphate and chloride; OJC, 2003). 
The data also have implications with respect to the interpretation of dynamic leaching experiments (e.g. CEN, 2005). Several authors (e.g. Grathwohl and Susset, 2009; LopezMeza et al., 2008; Hjelmar et al., 2007; Hjelmar, 1999) have shown that the liquid versus solid (L/S) ratio can be a very useful normalization parameter for comparing data from leaching tests performed on a given material at different scales and/or different percolation rates. This is not always the case however, as shown in Fig. 7 where Al and Cr data from Fig. 3 are plotted as a function of L/S ratio instead of time. As seen in this figure, the data do not collapse onto each other: due to the kinetics of the redox reactions that control the behaviour of these elements, leachate concentrations do not depend solely on the amount of water that has percolated through the waste per unit waste mass, but also on how much time metal aluminium has had to oxidize and on the stock of available reactive metal aluminium. This illustrates limitations of the $\mathrm{L} / \mathrm{S}$ ratio as a normalization parameter in the case of reactive constituents controlled by reaction kinetics.

\section{Acknowledgements}

The work presented herein was supported by the French Environmental Agency (ADEME) as part of the LIMULE project.

\section{References}

Abbas, Z., Moghaddam, A. P., Steenari, B.-M., 2003. Release of salts from municipal solid waste combustion residues. Waste Management 23, 291-305.

Abbas, Z., Steenari, B.-M., Lindqvist O., 2001. A study of Cr(VI) in ashes from fluidized bed combustion of municipal solid waste: leaching, secondary reactions and the applicability of some speciation methods Waste Management, 21, 725-739.

Appelo, C.A.J., Postma, D., 1999. Geochemistry, groundwater and pollution. A.A. Balkema, Rotterdam, Brookfield, 536 p.

Astrup, T., Dijkstra, J., Comans, R., Van der Sloot, H., Christensen, T., 2006. Geochemical modeling of leaching from MSWI air-pollution-control residues. Environ. Sci. Technol., 40, 3551-3557. 
Astrup T., Rosenblad C., Trapp S., Christensen T.H., 2005). Chromium Release from Waste Incineration Air-Pollution-Control Residues. Environ. Sci. Technol., 39(9), 3321 -3329.

Babushkin, V.I., Matveyev, G.M., Mchedlov-Petrossyan, O.P., 1985. Thermodynamics of Silicates. Springer-Verlag New York, New York, 459 p.

Blanc, P., Lassin, A., Piantone, P., 2008. THERMODDEM: a thermo-geochemical database for waste materials. In: Waste-Eng - 2nd international conference on engineering for waste valorisation, 3-5 June 2008, Patras, Greece.

CEN (2005) - CEN/TS 14405. Characterisation of waste - Leaching behaviour tests - Upflow percolation test (under specified conditions). European Committee for Standardisation. Brussels.

CEN (2002) - EN 12457-2. Characterisation of waste - Leaching - Compliance test for leaching of granular waste materials and sludges - Part 2: One stage batch test at a liquid to solid ratio of 10 1/kg for materials with particle size below $4 \mathrm{~mm}$ (without or with size reduction). European Committee for Standardisation. Brussels.

Damidot, D., Glasser, F.P., 1995. Investigation of the $\mathrm{CaO}-\mathrm{Al}_{2} \mathrm{O}_{3}-\mathrm{SiO}_{2}-\mathrm{H}_{2} \mathrm{O}$ system at $25^{\circ} \mathrm{C}$ by thermodynamic calculations. Cem. Concr. Res. 25, 22-28.

Damidot, D. and Glasser, F.P., 1993. Thermodynamic investigation of the CaO-A12O3 $\mathrm{CaSO} 4-\mathrm{H} 2 \mathrm{O}$ system at $25^{\circ} \mathrm{C}$ and the influence of $\mathrm{Na} 2 \mathrm{O}$, Cem. and Concr. Res. 23, 221238.

Damidot, D., Atkins, M., Kindness, A., Glasser, F.P., 1992. Sulphate attack on concrete: limits of the AFt stability domain, Cem. Concr. Res. 22, 229-234.

Dijkstra, J., van der Sloot, H.A., Comans, R.N.J., 2006. The leaching of major and tracé elements from MSWI bottom ash as a function of $\mathrm{pH}$ and time

Dijkstra, J., van der Sloot, H.A., Comans, R.N.J., 2002. Process identification and model development of contaminant transport in MSWI bottom ash. Waste Management 22, 531 541.

Eary, E.D., 1999. Geochemical and equilibrium trends in mine pit lakes. Applied Geochemistry, 14, 963-987.

Gogebakan, Z., Selçuk, N., 2009. Trace elements partitioning during co-firing biomass with lignite in a pilot-scale fluidized bed combustor. Journal of Hazardous Materials, 162, 11291134. 
Grathwohl, P., Susset, B., 2009. Comparison of percolation to batch and sequential leaching tests: Theory and data. Waste Management, 29, 2681-2688.

Guyonnet, D., Bodénan, F., Brons-Laot, Burnol A., Chateau, L., Crest, M., Méhu, J., Moszkowicz, P., Piantone, P., 2008. Multiple-scale leaching of a municipal solid waste incineration ash. Waste Management 28, 1963-1976.

Guyonnet, D., Bodénan, F., Brons-Laot, G., Burnol, A., Crest, M., Méhu, J., Moszkowicz, P., Piantone, P., Thomassin, J.-F., 2005. Projet LIMULE. Comportement à la lixiviation de cendres d'UIOM étudié à plusieurs échelles. Project LIMULE. Leaching behaviour of a MSW incineration ash examined at different scales. Final Report, BRGM/RP 54322 - FR, Orléans, France (in French).

Hjelmar, O., Holm, J., Crillesen,K., 2007. Utilisation of MSWI bottom ash as sub-base in road construction: First results from a large-scale test site. Journal of Hazardous Materials, 139(3) : 471-480.

Hjelmar, O., 1990. Leachate from land disposal of coal fly ash. Waste Management \& Research, 8, 429-449.

Hyks, J., Astrup, T., Christensen, T.H. (2009a). Leaching from MSWI bottom ash: Evaluation of non-equilibrium in column percolation experiments. Waste Management, 29(2): 522529.

Hyks, J., Astrup, T., Christensen, T.H. (2009b). Long-term leaching from MSWI airpollution-control residues: Leaching characterization and modeling. Journal of Hazardous Materials, 162(1): 80-91.

Lopez-Meza, S., Garrabrants, A., van der Sloot, H., Kosson, D.S., 2008. Comparison of the release of constituents from granular materials under batch and column testing. Waste Management, 28, 1853-1867.

MacPherson, D. R., Forbrich, L. R., 1937. Determination of Uncombined Lime in Portland Cement: The Ethylene Glycol Method. Ind. Eng. Chem. Anal. Ed., 9 (10), 451-453.

Möschner, G., Lothenbach, B., Rose, J., Ultich, A., Figi, R., Kretzschmar, R., 2008. Solubility of Fe-ettringite $\left(\mathrm{Ca}_{6}\left[\mathrm{Fe}(\mathrm{OH})_{6}\right]_{2}\left(\mathrm{SO}_{4}\right)_{3} 26 \mathrm{H}_{2} \mathrm{O}\right)$. Geochim. Cosmochim. Acta $72,1-18$.

OJC, 2003. Council Decision of 19 December 2002 establishing criteria and procedures for the acceptance of waste at landfills pursuant to Article 16 of Annex II to Directive 1999/31/EC. Official Journal of the European Communities L 11/27, 16 january 2003.

Parkhurst D.L., Appelo C.A.J., 1999. User's guide to PHREEQC (version 2) - A computer program for speciation, batch-reaction, one-dimensional transport, and inverse 
geochemical calculation. U.S. Geological Survey, Water-Resources Investigations. Report 99-4259, $312 \mathrm{pp}$.

Perkins R.B., Palmer, C.D., 1999. Solubility of ettringite $\left(\mathrm{Ca}_{6}\left[\mathrm{Al}(\mathrm{OH})_{6}\right]_{2}\left(\mathrm{SO}_{4}\right)_{3} 26 \mathrm{H}_{2} \mathrm{O}\right)$ at $5-$ $75^{\circ} \mathrm{C}$. Geochim. Cosmochim. Acta 63, 1969-1980.

Piantone, P., Bodénan, F., Chatelet-Snidaro, L., 2004. Mineralogical study of secondary mineral phases from weathered MSWI bottom ash: implications for the modelling and trapping of heavy metals. Applied Geochemistry, 19, 1891-1904.

Pouchou J.L., Pichoir F., 1991. Quantitative analysis of homogeneous or stratified microvolumes applying the model "PAP". In: Heinrich KFJ, Newbury DE (eds) Electron probe quantitation. Plenum press, New York, 31-75.

Reardon, E.J., 1990. An Ion Interaction Model for the Determination of Chemical Equilibria in Cement/Water Systems. Cem. Concr. Res., 20:2, 175-92.

Rhyner, C.R., Schwatz, L.J., Webger, R.B., Kohrell, M.G., 1995. Waste Management and Resources Recovery. Lewis Publishers, New York.

Sandell, E.B., 1951. Micro Determination of Water by the Penfield Method. Microchimica Acta, 38(4): 487-491.

Taylor, H. F. 1990. Cement Chemistry. Academic Press, London, U.K.

Toledo, J.M., Corella, J., Corella, L.M., 2005. The partitioning of heavy metals in inceineration of sludges and waste in a bubbling fluidized bed. 2. Interpretation of results with a conceptual model. Journal of Hazardous Materials B126, 158-168.

Valk, 1994. Atmospheric fluidized bed coal combustion: research development and application. Coal Science \& Technology, 22, Elsevier, 478 pp.

Van de Velden, M., Dewil, R., Baeyens, J., Josson, L., Lanssens, P., 2008. The distribution of heavy metals during fluidized bed combustion of sludge (FBSC). Journal of Hazardous Materials, 151, 96-102.

Young, R.S., 1974. Chemical Phase Analysis. Griffin, London. 
Table 1

Global chemical compositions

\begin{tabular}{|c|c|c|c|c|c|}
\hline $\mathrm{Wt} \% \mathrm{DM}$ & $\begin{array}{l}\text { Fresh } \\
\text { sand }\end{array}$ & $\begin{array}{c}\text { Fresh } \\
\text { ash-sand* }\end{array}$ & $\begin{array}{l}\text { Fresh } \\
\text { ash** }^{* *}\end{array}$ & $\begin{array}{l}\text { Leached } \\
\text { ash-sand* }\end{array}$ & Hopper ash*** \\
\hline $\mathrm{Al}_{2} \mathrm{O}_{3}$ total & 9.2 & 11.5 & 13.8 & 10.8 & 13.25 \\
\hline $\mathrm{CaO}$ & 0.9 & 7.6 & 14.3 & 8.7 & 7.68 \\
\hline $\mathrm{Fe}_{2} \mathrm{O}_{3}$ total & 1.58 & 3.64 & 5.7 & 2.9 & 4.92 \\
\hline $\mathrm{K}_{2} \mathrm{O}$ & 3.83 & 3.0 & 2.17 & 2.8 & 2.41 \\
\hline $\mathrm{MgO}$ & 0.6 & 1.3 & 2 & 1.4 & 1.30 \\
\hline $\mathrm{MnO}$ & 0.04 & 0.07 & 0.1 & 0.1 & 0.13 \\
\hline $\mathrm{Na}_{2} \mathrm{O}$ & 1.7 & 1.7 & 1.7 & $\mathrm{~nm}$ & 3.43 \\
\hline $\mathrm{P}_{2} \mathrm{O}_{5}$ & 0.1 & 1.25 & 2.4 & 1.1 & 1.07 \\
\hline $\mathrm{SiO}_{2}$ & 80.8 & 67.4 & 54 & 60.4 & 64.35 \\
\hline $\mathrm{TiO}_{2}$ & 0.32 & 0.69 & 1.06 & 0.6 & 0.93 \\
\hline $\mathrm{Cl}$ & n.m. & 0.43 & - & n.m. & n.m. \\
\hline C total & n.m. & 0.2 & - & n.m. & n.m. \\
\hline COT & n.m. & $<0.05$ & - & n.m. & 0.08 \\
\hline$S$ total & n.m. & 0.26 & - & n.m. & 0.24 \\
\hline LOI & & 2.16 & & & \\
\hline $\mathrm{Al}^{0}$ & $<0.1$ & 1.4 & 2.8 & 0.6 & n.m. \\
\hline $\mathrm{H}_{2} \mathrm{O}$ crystal. & n.m. & 0.67 & - & 1.7 & n.m. \\
\hline \multicolumn{6}{|l|}{$\mathrm{mg} / \mathrm{kg} \mathrm{DM}$} \\
\hline $\mathrm{Ag}$ & $<0.2$ & 4.3 & 8.6 & 4.3 & 0.8 \\
\hline As & 24 & 46 & 68 & 28 & 29 \\
\hline $\mathrm{Ba}$ & 680 & 955 & 1230 & 970 & 1300 \\
\hline $\mathrm{Cd}$ & $<2$ & 4 & 8 & 3 & 6.4 \\
\hline Co & 7 & 61 & 115 & 59 & 19 \\
\hline Cr total & 28 & 168 & 308 & 185 & 283 \\
\hline $\mathrm{Cu}$ & 11 & 1021 & 2031 & 989 & 3150 \\
\hline Mo & $<5$ & 8 & 16 & $<5$ & 28 \\
\hline $\mathrm{Ni}$ & 28 & 63 & 98 & 55 & 88 \\
\hline $\mathrm{Pb}$ & 39 & 473 & 907 & 473 & 682 \\
\hline $\mathrm{Sb}$ & $<10$ & 44 & 88 & 52 & n.m. \\
\hline $\mathrm{Sn}$ & $<10$ & 155 & 310 & 234 & 123 \\
\hline $\mathrm{Sr}$ & 171 & 235 & 299 & 187 & 229 \\
\hline V & 18 & 24 & 30 & 33 & 44 \\
\hline $\mathrm{Zn}$ & 38 & 2053 & 4068 & 2268 & 2790 \\
\hline $\mathrm{Zr}$ & 64 & 48 & 32 & 91 & 177 \\
\hline
\end{tabular}

$\mathrm{LOI}=$ loss on ignition at $1000^{\circ} \mathrm{C} ; \mathrm{DM}=$ dry matter; n.m. $=$ not measured $; *=$ data from

Guyonnet et al. (2007); ** = calculated as difference between ash-sand and sand; $* * *=$ data from Table 1 of Abbas et al. (2001) 
To be published in Waste Management (2010) - Bodénan et al.

\section{Table 2}

Results of batch leaching test (at $\mathrm{L} / \mathrm{S}=10 \mathrm{~L} / \mathrm{Kg}$ ), performed on samples collected at different depths from the large column after 18 months leaching

\begin{tabular}{lccccccc}
\hline Sampling depth $(\mathrm{m})$ & Fresh* & $0-1$ & $1-2$ & $2-3$ & $3-4$ & $4-5$ & Composite \\
\hline $\begin{array}{l}\text { Average L/S ratio after } \\
18 \text { months in column }\end{array}$ & - & 20 & 13.2 & 6.8 & 4.6 & 3.5 & $20-3.0$ \\
\hline $\mathrm{pH}$ & 10.3 & 10.7 & 10.7 & 10.85 & 10.8 & 10.85 & 11 \\
Conductivity $(\mu \mathrm{S} / \mathrm{cm})$ & 1580 & 303 & 300 & 365 & 368 & 378 & 340 \\
$\mathrm{mg} /$ Kg dry matter & & & & & & & \\
$\mathrm{Al}$ & 844 & 85.8 & 268.7 & 295.9 & 328.4 & 339.4 & 214.7 \\
$\mathrm{Ca}$ & 2312 & 669 & 700 & 811 & 891 & 909 & 1074 \\
$\mathrm{Cl}$ & 2697 & 14.1 & $<10$ & $<10$ & $<10$ & $<10$ & 18.7 \\
$\mathrm{SO}_{4}$ & 1938 & 654 & 526 & 570 & 632 & 721 & 677 \\
$\mathrm{Cr}$ total & 0.27 & 0.41 & 0.21 & 0.25 & 0.3 & 0.32 & 0.47 \\
$\mathrm{Cr}(\mathrm{VI})$ & 0.26 & n.m. & n.m. & n.m. & n.m. & n.m. & 0.40 \\
\hline
\end{tabular}

n.m. $=$ not measured; $*=$ data from Guyonnet et al. (2007) 
To be published in Waste Management (2010) - Bodénan et al.

Table 3

Thermodynamic constants of the main mineral phases considered in the geochemical modelling

\begin{tabular}{|c|c|c|c|c|}
\hline \multirow{2}{*}{$\begin{array}{l}\text { Phase } \\
\text { Carbonates }\end{array}$} & \multicolumn{2}{|c|}{$\begin{array}{l}\text { General formula and } \\
\text { cement nomenclature (in brackets) }\end{array}$} & \multirow[t]{2}{*}{$\log \mathrm{K}$} & \multirow[t]{2}{*}{ Ref.* } \\
\hline & & & & \\
\hline & $\mathrm{CaCO}_{3}$ & & 1.99 & 1 \\
\hline Barytocalcite & $\mathrm{BaCa}\left(\mathrm{CO}_{3}\right)_{2}$ & & 2.74 & 1 \\
\hline Calcite & $\mathrm{CaCO}_{3}$ & {$[\mathrm{CC}]$} & 1.85 & 1 \\
\hline Strontianite & $\mathrm{SrCO}_{3}$ & & -0.31 & 1 \\
\hline Monohydrocalcite & $\mathrm{CaCO}_{3}: \mathrm{H}_{2} \mathrm{O}$ & & 2.68 & 1 \\
\hline Monocarbo-aluminate & $\mathrm{Ca}_{4} \mathrm{Al}_{2} \mathrm{CO}_{9}: 10 \mathrm{H}_{2} \mathrm{O}$ & {$[\mathrm{mCA}]$} & 80.42 & 2 \\
\hline Hemicarbo-aluminate & $\mathrm{Ca}_{8} \mathrm{Al}_{4} \mathrm{CO}_{16}: 21 \mathrm{H}_{2} \mathrm{O}$ & {$[\mathrm{hCA}]$} & 181.97 & 2 \\
\hline \multicolumn{5}{|c|}{ Hydrated cement phases (CSH, CAH, CASH) } \\
\hline Straëtlengite & $\mathrm{Ca}_{2} \mathrm{Al}_{2} \mathrm{SiO}_{7}: 8 \mathrm{H}_{2} \mathrm{O}$ & [C2A2SH8] & 49.71 & 3 \\
\hline Hydrogarnet (katoite) & $\mathrm{Ca}_{3} \mathrm{Al}_{2} \mathrm{H}_{12} \mathrm{O}_{12}$ & [C3AH6] & 79.14 & 4 \\
\hline $\mathrm{C}_{4} \mathrm{AH}_{13}$ & $\mathrm{Ca}_{4} \mathrm{Al}_{2} \mathrm{O}_{20} \mathrm{H}_{26}$ & [C4AH13, AFm] & 102.02 & 5 \\
\hline $\mathrm{Ca}_{2} \mathrm{Al}_{2} \mathrm{O}_{5}: 8 \mathrm{H}_{2} \mathrm{O}$ & & & 59.57 & 1 \\
\hline \multicolumn{5}{|l|}{ Sulphates } \\
\hline Anhydrite & $\mathrm{CaSO}_{4}$ & & -4.30 & 1 \\
\hline Barite & $\mathrm{BaSO}_{4}$ & & -9.97 & 1 \\
\hline Bassanite & $\mathrm{CaSO}_{4}: 0.5 \mathrm{H}_{2} \mathrm{O}$ & & -3.66 & 1 \\
\hline Ettringite & $\mathrm{Ca}_{6} \mathrm{Al}_{2}\left(\mathrm{SO}_{4}\right)_{3}(\mathrm{OH})_{12}$ & {$[\mathrm{AFt}]$} & 57.08 & 6 \\
\hline Gypsum & $\mathrm{CaSO}_{4}: 2 \mathrm{H}_{2} \mathrm{O}$ & & -4.48 & 1 \\
\hline \multicolumn{5}{|l|}{ Other phases } \\
\hline $\mathrm{Al}(\mathrm{OH})_{3} \mu \mathrm{C}$ & $\mathrm{Al}(\mathrm{OH})_{3}$ & & 9.35 & 7 \\
\hline Gibbsite & $\mathrm{Al}(\mathrm{OH})_{3}$ & [AH3] & 7.76 & 1 \\
\hline Portlandite & $\mathrm{Ca}(\mathrm{OH})_{2}$ & {$[\mathrm{CH}]$} & 22.81 & 8 \\
\hline Quartz & $\mathrm{SiO}_{2}$ & & -4.00 & 1 \\
\hline Tridymite & $\mathrm{SiO}_{2}$ & & -3.83 & 1 \\
\hline Pseudowollastonite & $\mathrm{CaSiO}_{3}$ & {$[\mathrm{CS}]$} & 14.00 & 1 \\
\hline Wollastonite & $\mathrm{CaSiO}_{3}$ & {$[\mathrm{CS}]$} & 13.76 & 1 \\
\hline Larnite & $\mathrm{Ca}_{2} \mathrm{SiO}_{4}$ & {$[\mathrm{C} 2 \mathrm{~S}]$} & 38.47 & 1 \\
\hline Tenorite & $\mathrm{CuO}$ & & 7.66 & 1 \\
\hline Zincite & $\mathrm{ZnO}$ & & 11.21 & 1 \\
\hline $\mathrm{Zn}(\mathrm{OH})_{2}$-beta & $\mathrm{Zn}(\mathrm{OH})_{2}$ & & 11.93 & 1 \\
\hline
\end{tabular}

Ref 1: Llnl.dat ; 2: Damidot et al. (1994); 3: Damidot and Glasser, (1993, 1995); 4: Damidot et al. (1992);

5: Babushkin et al. (1985); 6: Perkins and Palmer, (1999); Möschner et al. (2008); 7: Eary, (1999); 8: Reardon, (1990) 
a
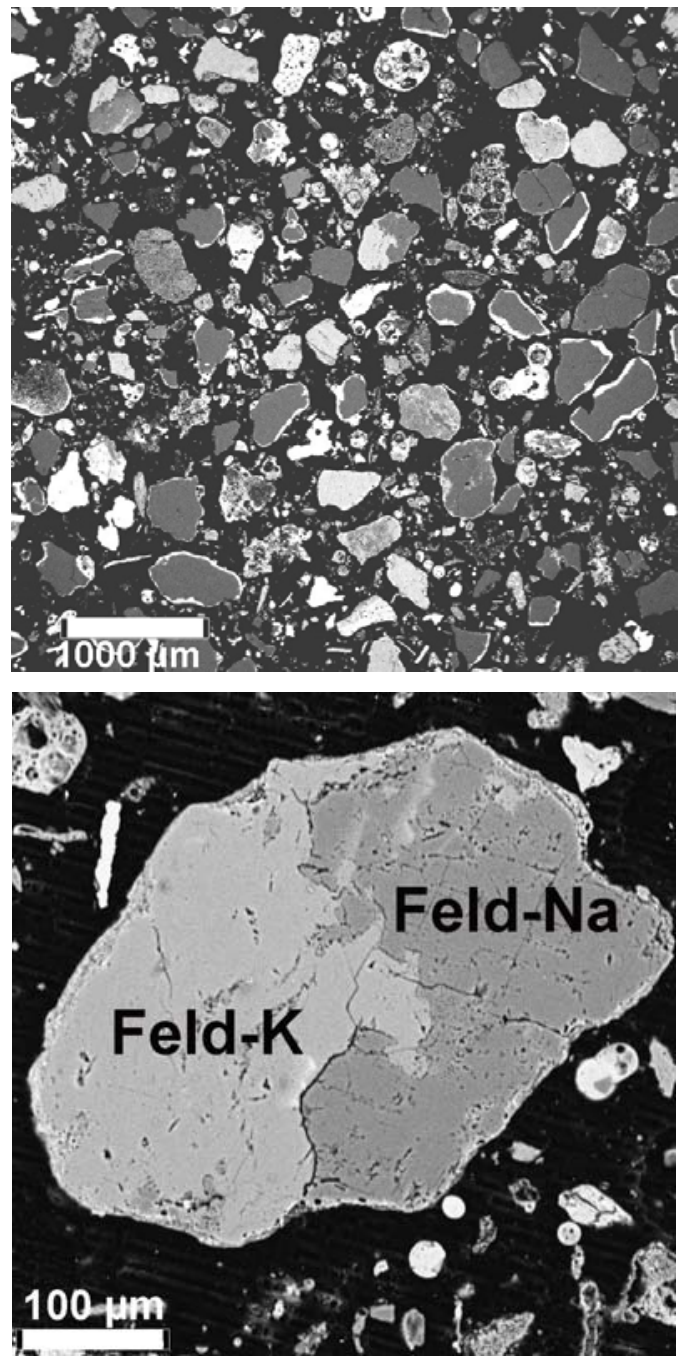

b

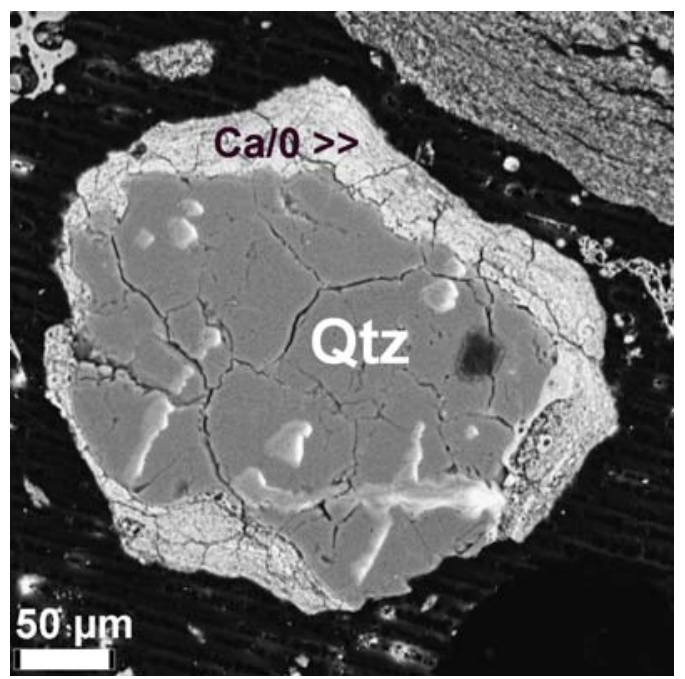

$\mathrm{d}$

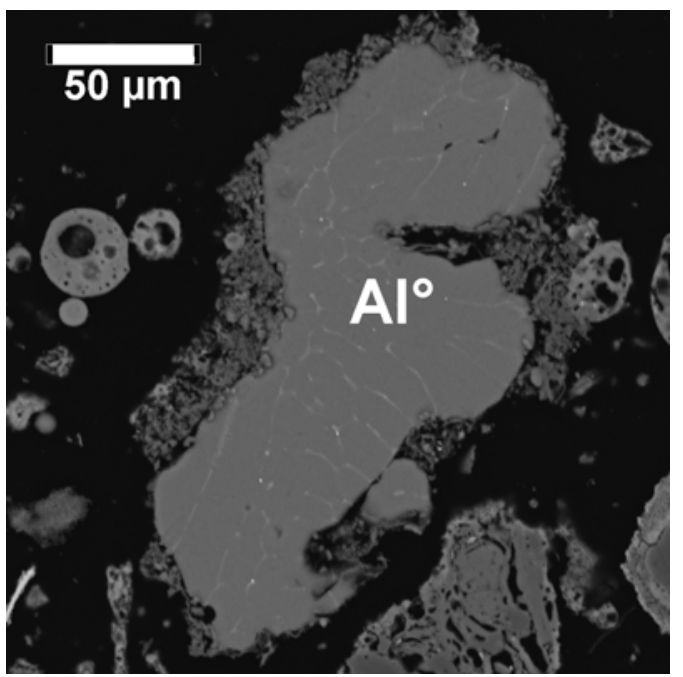

Fig.1. SEM images of fresh ash; (a) global ; (b) quartz with Ca-bearing coating ; (d) Feldspar ; (d) $\mathrm{Al}^{0}$. 
a

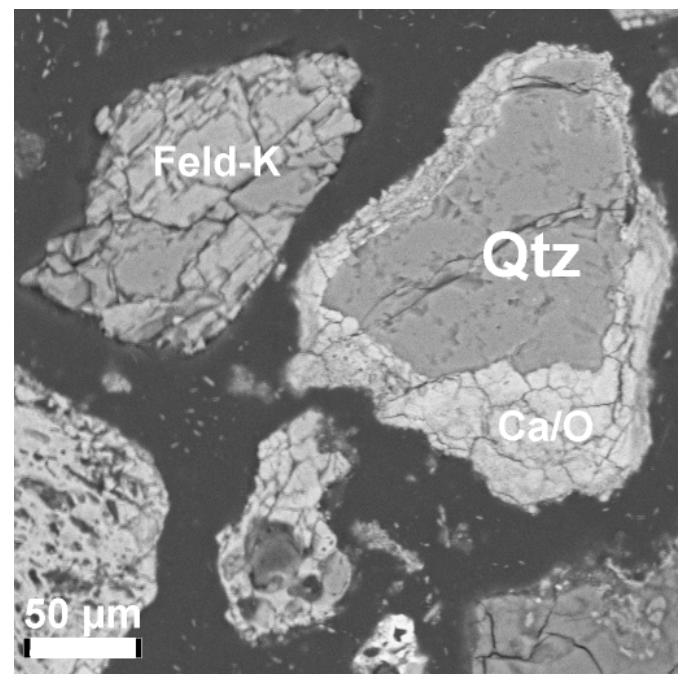

c

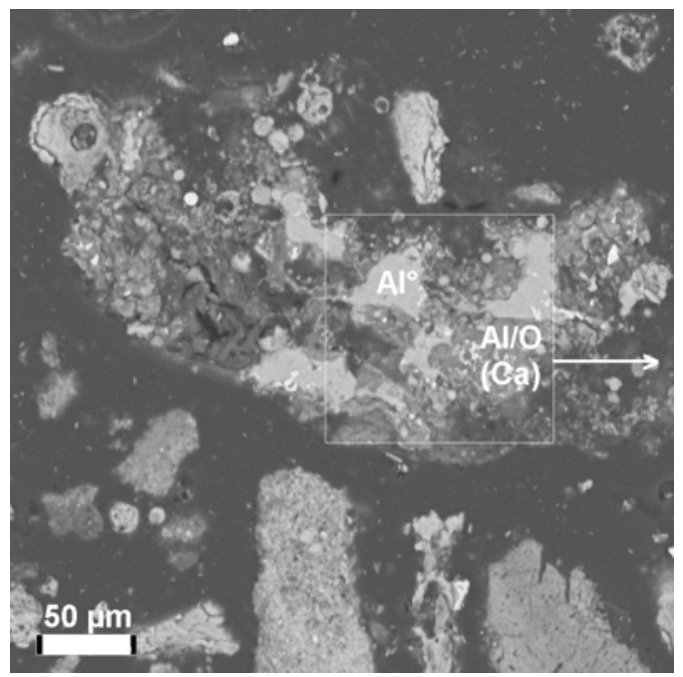

$\mathrm{b}$

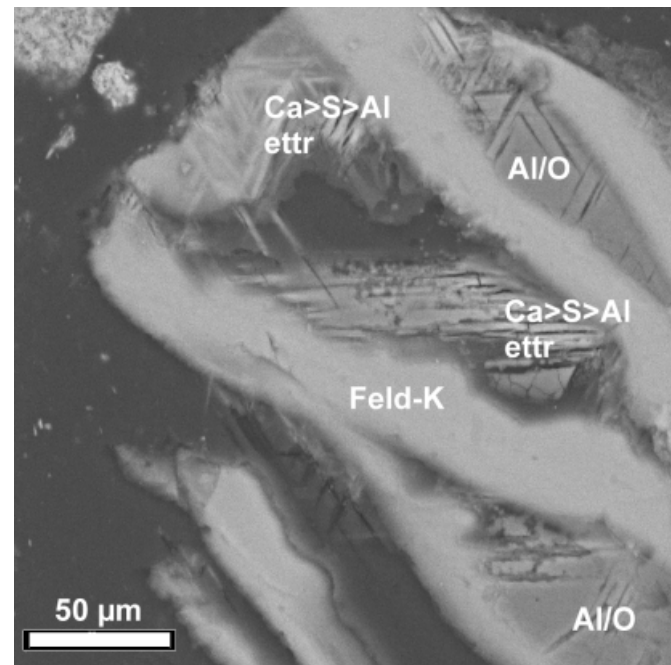

d

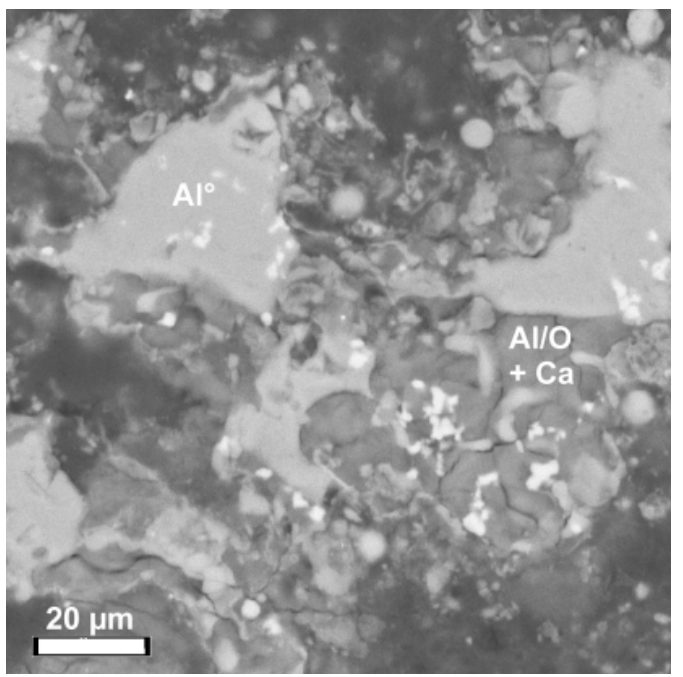

Fig.2. SEM images of ash-sand mixture after 18 months of dynamic leaching; (a) quartz and altered feldspar grains; (b) precipitation of $\mathrm{Al}(\mathrm{OH})_{3}$ and ettringite (c) residual $\mathrm{Al}^{0}$ grain and (d) focus on precipitation of $\mathrm{Al}(\mathrm{OH})_{3}$. 

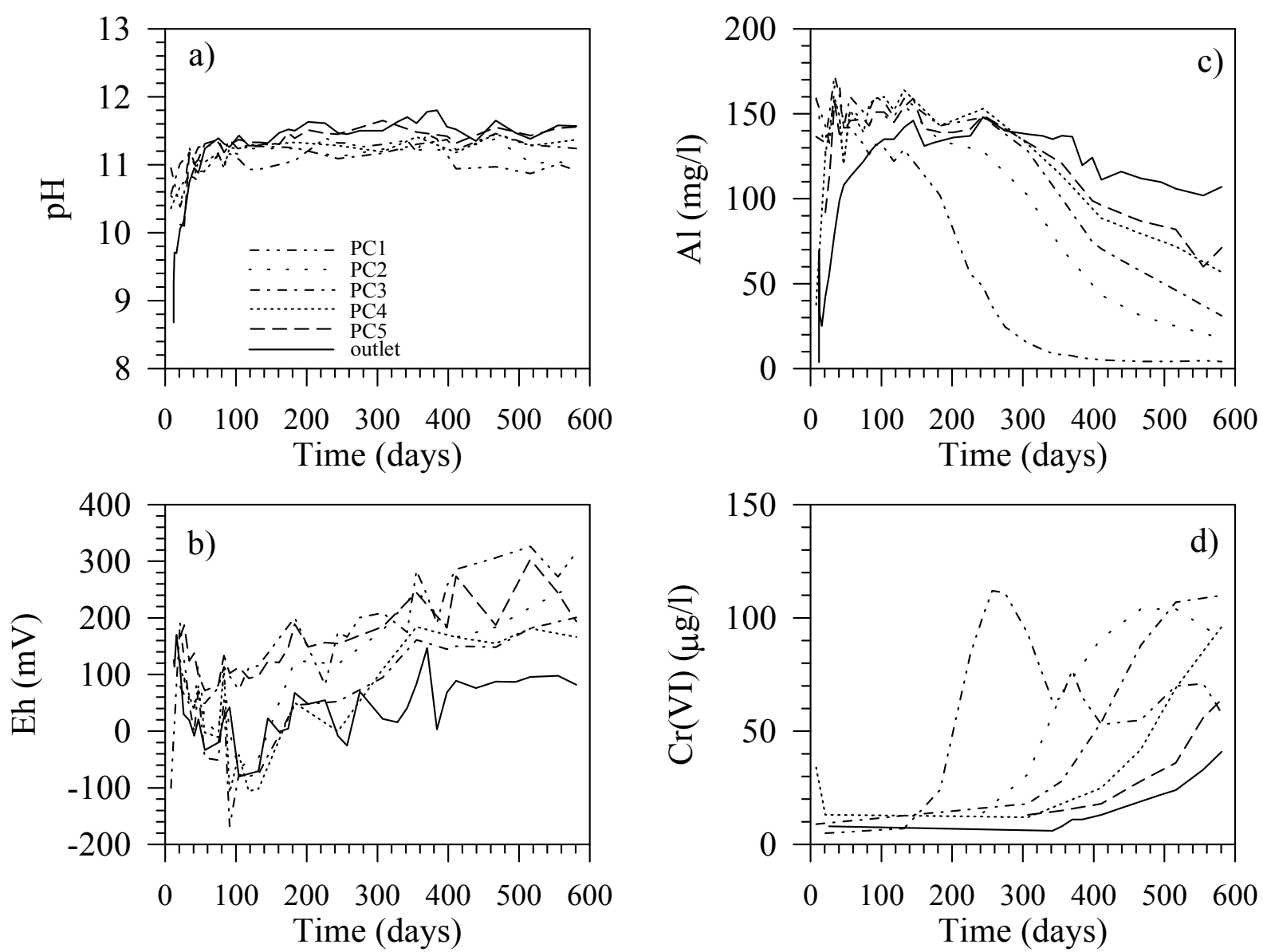

Fig.3. Evolution of (a) pH, (b) Eh, (c) Al and (d) $\mathrm{Cr}(\mathrm{VI})$ in the porewater at different depths in the column, as a function of time. PC1: $0.8 \mathrm{~m}$; PC2: $1.82 \mathrm{~m}$; PC3: $2.54 \mathrm{~m}$; PC4: $3.55 \mathrm{~m}$, PC5: $4.36 \mathrm{~m}$; outlet: $5 \mathrm{~m}$ from column inlet. 

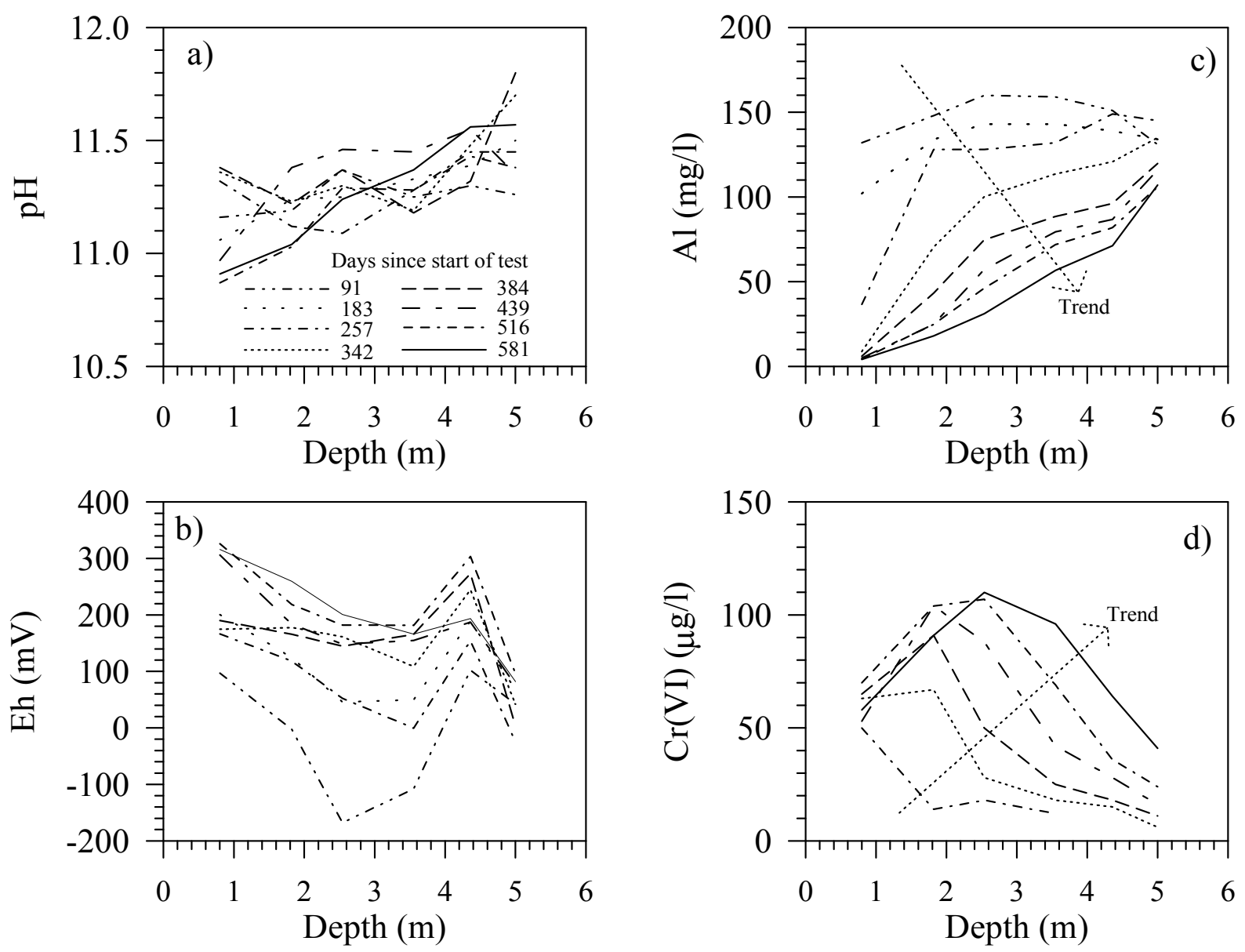

Fig.4. Evolution of (a) pH, (b) Eh, (c) Al and (d) $\mathrm{Cr}$ (VI) in the porewater at different times as a function of depth in the column. 

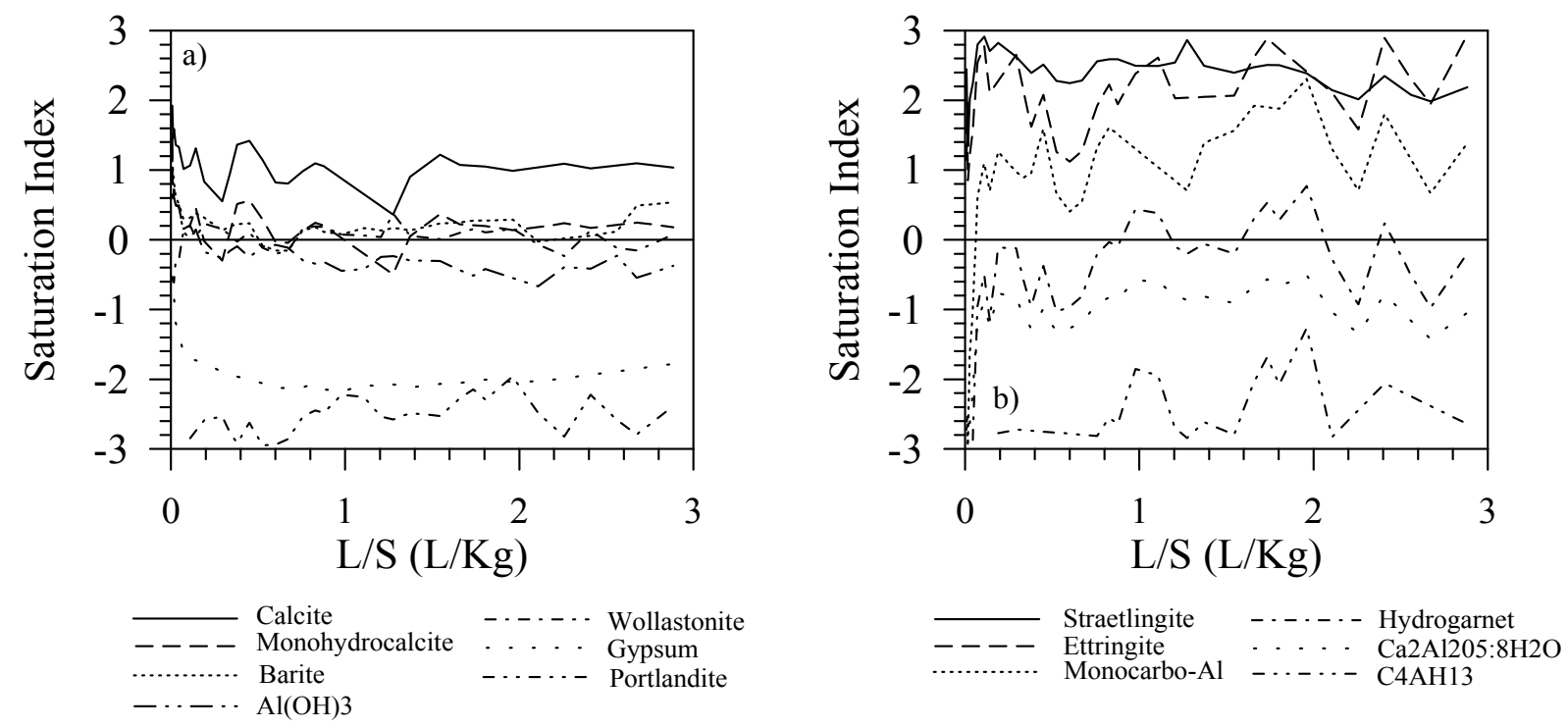

Fig.5. Evolution of saturation indices of 6 mineral phases, as a function of L/S ratio, calculated in samples at the outlet of the large column. 
To be published in Waste Management (2010) - Bodénan et al.
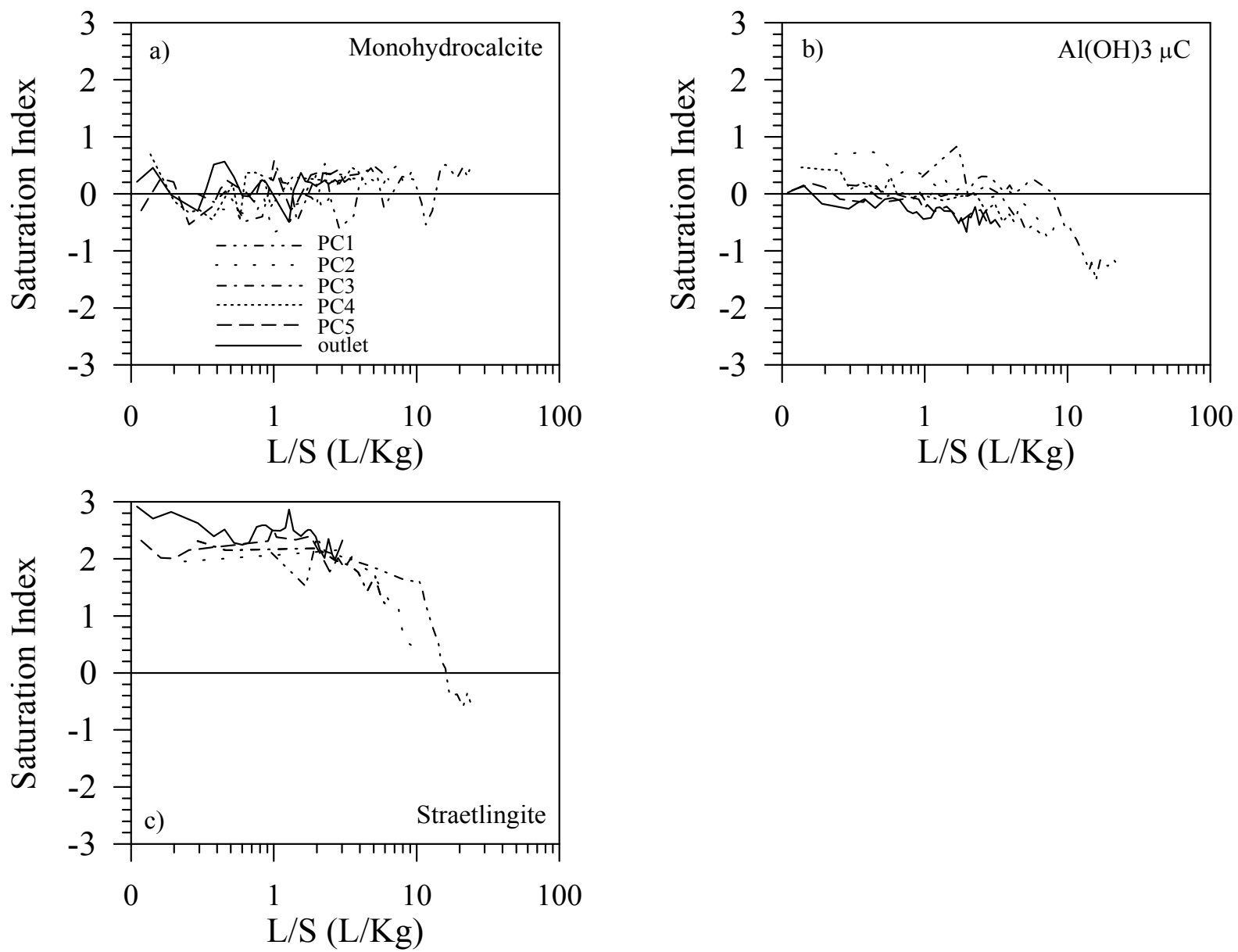

Fig.6. Evolution of saturation indices for three mineral phases (see Table 3); (a) Monohydrocalcite, (b) Micro-crystalline Gibbsite, (c) Straetlingite, as a function of L/S ratios, calculated in samples from the porous cups (PC) and at the outlet of the large column 
To be published in Waste Management (2010) - Bodénan et al.
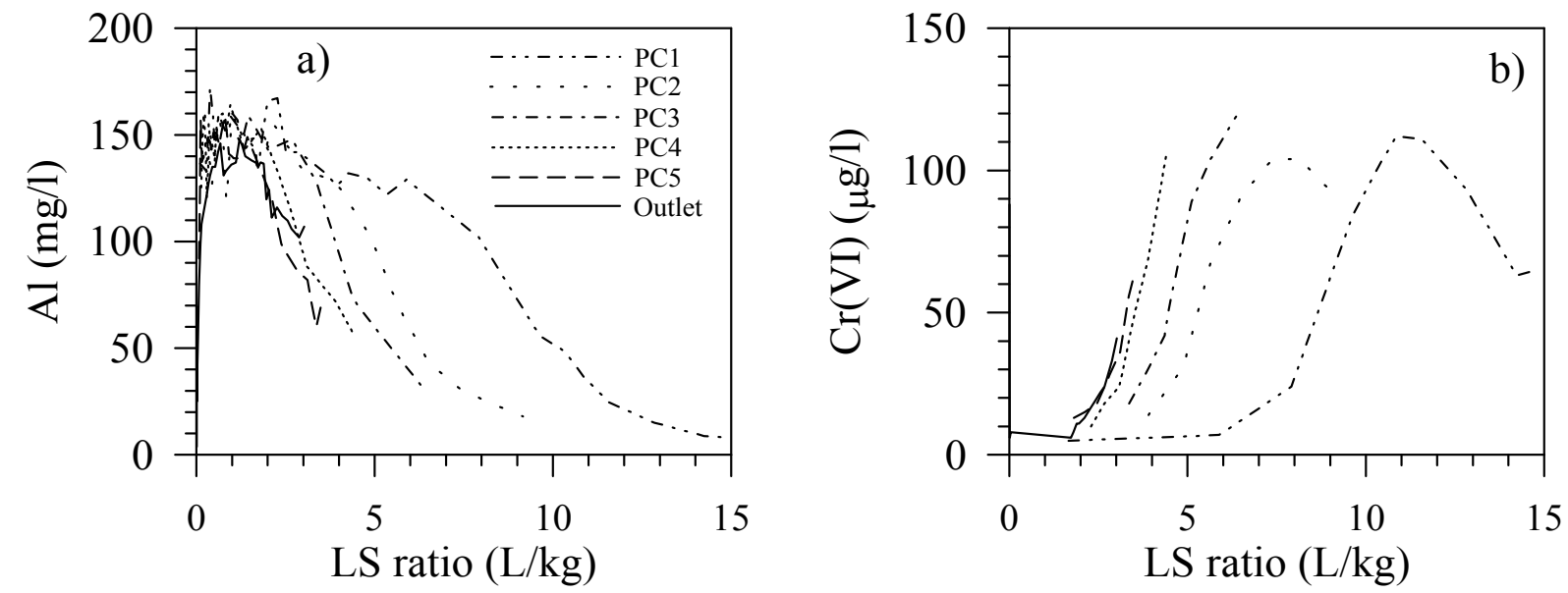

Fig.7. Evolution of (a) $\mathrm{Al}$ and (b) $\mathrm{Cr}(\mathrm{VI})$ in the porewater at different depths in the column, as a function of $\mathrm{L} / \mathrm{S}$ ratio. 